\title{
COMPUTATIONAL SOCIOLOGY: APPLICATION AND DEVELOPMENT
}

\author{
Yanu E. Prasetyo \\ Researcher at Indonesian Institute of Sciences (LIPI), Postgraduate Student of Rural \\ Sociology at University of Missouri, United State. email: yepw33@mail.missouri.edu/ \\ lipi002@lipi.go.id/yanuprasetyo85@gmail.com
}

\begin{abstract}
Abstrak
Seiring dengan perkembangan riset "Big Data" dan penggunaan riset berbasis komputer serta internet yang kian massif, perkembangan studi dengan pendekatan sosiologi komputasional juga semakin mendapat perhatian. Tren riset dan studi sosiologi komputasional, seperti permodelan berbasis agen atau analisis jejaring sosial, menjadi penanda baru minat para sarjana ilmu sosial di seluruh dunia untuk terus mengembangkan pendekatan riset interdisiplin yang aplikatif. Artikel ini mencoba memetakan tren dan perkembangan kajian sosiologi komputasional melalui tinjauan sistematis dan analisis bibliometrik terhadap publikasi ilmiah di pusat data Scopus. Dengan metode ini kita dapat memetakan berbagai topik, konsep-konsep penting dan kluster kajian kontemporer tentang sosiologi komputasi, termasuk jurnal-jurnal internasional yang memiliki fokus dan ketertarikan pada pengembangan studi ini.
\end{abstract}

Kata Kunci: Analisis Bibliometrik, Scopus, Sosiologi Komputasional

\begin{abstract}
Along with the popularity of research on Big Data and the increasingly massive use of computer as well as internet-based research, the development of studies with a computational sociology approach has also received more attention. Computational sociology approach such as agent-based modeling or social network analysis has become a new landmark of the interest of social scientist around the world to continue develops suitable interdisciplinary research approaches. This article makes mapping and visualizing the trends and developments of computational sociology studies through a systematic review and bibliometric analysis of scientific publications in the Scopus database. Concepts and clusters of studies on contemporary computational sociology are discussed, including international journals that have a focus and interest in this approach and research area.
\end{abstract}

Keywords: Bibliometric analysis, Scopus, Computational Sociology 


\section{Background}

The advancement of science and technology has altered the landscape of science and human civilization including the model of social science such as sociology which has undergone a transformation. Hummon and Fararo ${ }^{1}$, in their article written in 1995, have predicted the phenomena. They conveyed there are three aspects as well as basic elements of the development of science. Firstly, it is theoretical in which every field of sciences possesses the theoretical element attempting to highlight a phenomenon from a distinctive point of view. Secondly, it is empirical in which a theory is commonly developed, revised or conveyed from findings of empirical data. Thirdly, it is computational in which it is unpopular among sociologists in the past. However, along with the rapid advancement of the computer, it is considered by many researchers and social scientists to integrate the elements in developing social theories. In a complex digital era, a reliable approach of understanding, predicting, and manipulating complexity of social issues as complex adaptive systems is needed (Miller \& Page, 2007). The elements will be the concern of the article.

Computation possesses several fundamental justifications in development of sociology in the present and future where one of them derives from computers, internet, and other technologies to generate simulation models assisting to observe social phenomena both theoretically and empirically. As a dynamic model, a computer simulation will help to prove and develop a social theory to be more systematic, measurable and relatively cheaper. When sociology is massively adopted to elucidate or deal with the complexity of social issues, the aim of developing sociological theory is closer to be achieved. (Brent et al., 2000).

Nowadays, one of the fundamental changes in the digital era is the pattern of collecting a range of digital data that are able to be utilized for various objectives. We live in an era where every human activity can be recorded digitally. Although there has been myriad of skepticism about the possibility in replacing conventional social science approaches, it is still possible to encourage scientists focusing on social interaction by utilizing the abundance of data (Halford \& Savage, 2017). Visualization techniques, analysis of social networks and artificial society approaches are rapidly developing and being contemporary social science developments (Alvarez, 2016). The article highlights how application and development of computational sociology research particularly those written in the publication of scientific journals of sociology and other social science fields.

\section{Method}

In a systematic review of the application and development of computational

1 Hummon \& Fararo (1995), The Emergence of Computational Sociology, Journal of Mathematical Sociology 
sociology, the author utilizes a bibliometric analysis method and systematic review of an article or international scientific publication as primary data to be analyzed. Several steps in collecting data are as follows: firstly, the author determines the keyword used to search for the related article in the Scopus data center. Scopus ${ }^{2}$ generally is a digital corpus storing thousands and millions of scientific articles worldwide. Thus, specific keywords are needed allowing the author to retrieve an article through the search engine on the Scopus database in which sociology and computational are keywords used in the search of the article.

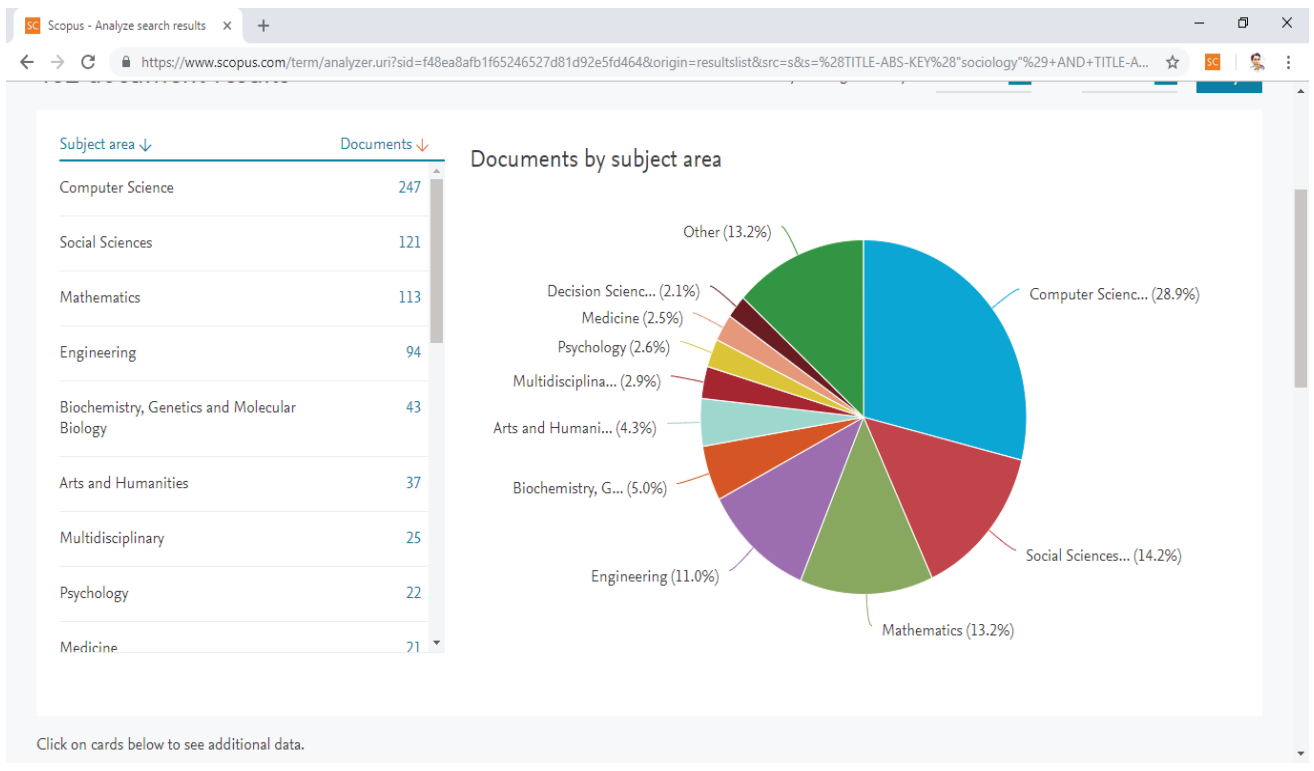

Figure 1. Scientific publication in the Scopus data center related to keywords of sociology and computational in accordance with the science field $(\mathrm{N}=428) .28 .9 \%$ of articles derived from computer science disciplines and $14.2 \%$ derived from social science. This research only analyses articles deriving from social science fields.

The search results ${ }^{3}$ utilizing two key words results in 482 articles from various scientific disciplines such as computer science, social science, mathematics, psychology, and so on (see figure 1). In obtaining a more accurate database, the author narrows research by limiting to the branch of social science. Moreover, the author limits only articles published in the English language that will be included in the analysis. Therefore, there are seventy reliable articles in the research topic. The following is a complete query in article data search on Scopus.

Secondly, the author then screens every article in the database ensuring whether the available articles reflect the application of computational sociology or not after gaining seventy articles needed. The author utilizes criteria for exclusion and inclusion

2 is an abstract database and the best citation on literature or peer review of scientific publications both in the pattern of journal or proceeding. https://www.scopus.com/

3 Observing was conducted on 7 and 25 October 2018. 
in the process in which articles that do not derive from social science fields and are not related to the application of computational sociology will exclude in further analysis. Hence, the author obtained the final dataset ${ }^{4}$ above thirty-six articles. Thirdly, it is then grouped into clusters, journals and valuable concepts utilized in this research as the main discussion.

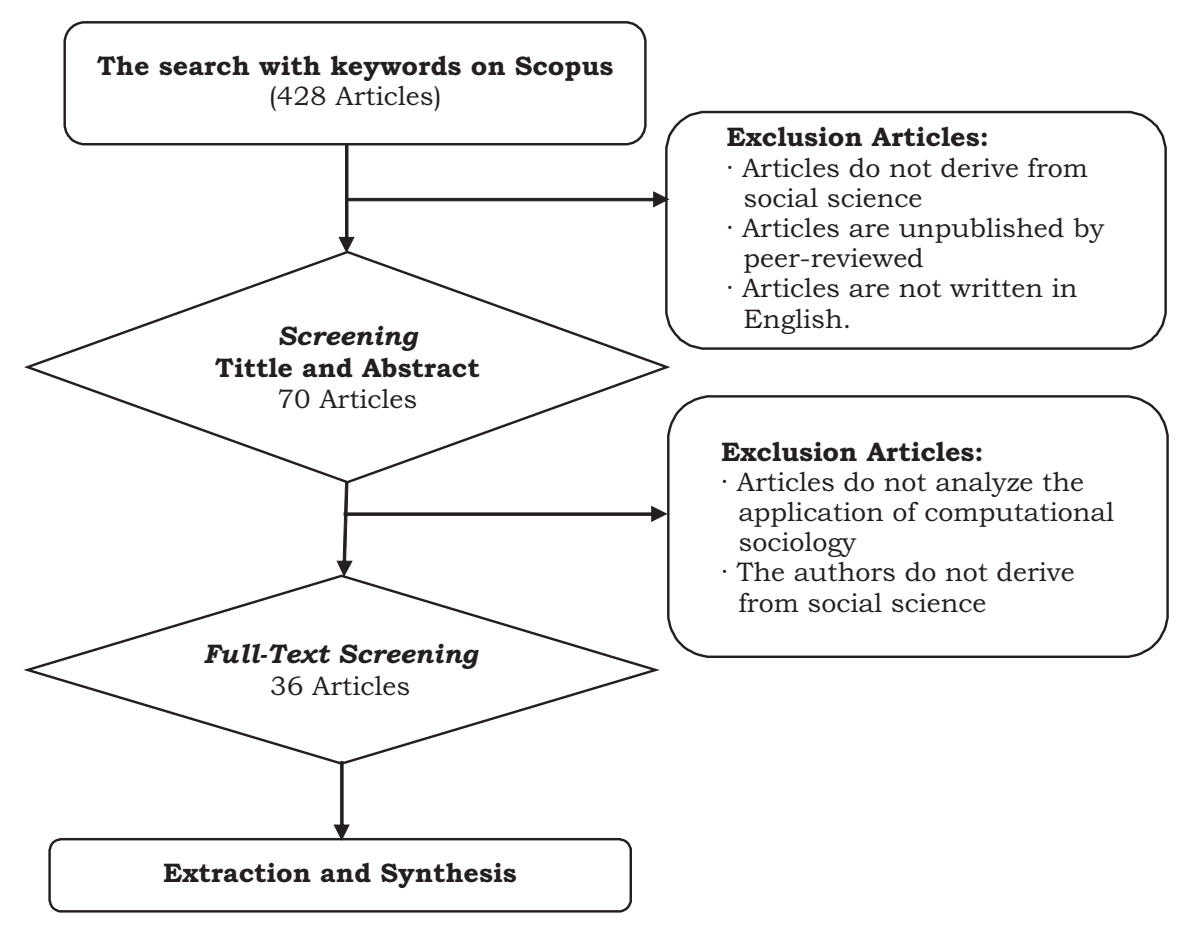

Figure 2. Systematic Review

\section{Result and Discussion}

A systematic review of literature related to computational sociology in Scopus reveals that publication on the topic spreads in various types of international journals. In addition, the development of computational sociology idea is unlimited to particular journal while it is accepted and spread in various journals with diverse disciplinary backgrounds. In Table 1, there are 36 articles analyzing computational sociology, however, there is no dominant journal. Moreover, there are three articles published respectively by Poetics and Social Science Computer Review. Poetics is a journal focusing on publishing interdisciplinary research both theoretical and empirical in the fields of culture, media, and art. Nevertheless, main disciplines encompassing the journal are sociology, psychology, communication, and economics ${ }^{5}$. On the one hand, Social Science Review is an interdisciplinary journal focusing on computer application research for social science and social impact of information

4 Analysed dataset can be found in attachment 1.

5 Official website of Jurnal Poetics: https://www.journals.elsevier.com/poetics/ ISSN: 0304-422X, impact factor: 1.649 
technology 6 . From the description of the journals, it can be found that the field of research in computational sociology has indeed spread to interdisciplinary. Even if added to the list of subsequent journals such as American Sociologist, Sociological Methodology, Cultural Sociology, Journal Mathematical Sociology, the diversity of application will be very obvious.

Table 1. The list of international journals publishing computational sociology research result on Scopus $(\mathbf{N}=36)$

\begin{tabular}{lcc}
\hline \multicolumn{1}{c}{ Source Title } & Number of Article & \% \\
\hline Poetics & 3 & 8.33 \\
\hline Social Science Computer Review & 3 & 8.33 \\
\hline Social Science Research & 2 & 5.56 \\
\hline IEEE Transactions on Computational Social Systems & 2 & 5.56 \\
\hline American Sociologist & 2 & 5.56 \\
\hline Sociological Methodology & 2 & 5.56 \\
\hline Sociological Methods and Research & 2 & 5.56 \\
\hline Cultural Sociology & 1 & 2.78 \\
\hline Environmental Sociology & 1 & 2.78 \\
\hline User Modeling and User-Adapted Interaction & 1 & 2.78 \\
\hline Sociology & 1 & 2.78 \\
\hline Artificial Intelligence Review & 1 & 2.78 \\
\hline JASSS & 1 & 2.78 \\
\hline Scientometrics & 1 & 2.78 \\
\hline Cyberpsychology, Behavior, and Social Networking & 1 & 2.78 \\
\hline Social Science and Medicine & 1 & 2.78 \\
\hline Sociological Science & 1 & 2.78 \\
\hline Mind and Society & 1 & 2.78 \\
\hline American Sociological Review & 1 & 2.78 \\
\hline Social Currents & 1 & 2.78 \\
\hline Papers & 1 & 2.78 \\
\hline Sociological Theory & 1 & 2.78 \\
\hline New Media and Society & 1 & 2.78 \\
\hline Social Science Information & 1 & 2.78 \\
\hline Journal of Social and Political Psychology & 1 & 2.78 \\
\hline International Studies Quarterly & 1 & \\
\hline The Journal of Mathematical Sociology & 1 & \\
\hline Total (\%) & 1 & \\
\hline & 1 & \\
\hline
\end{tabular}

Then, what are topics most frequently appeared and answered with the current computational sociology approach? What are the fundamental concepts? As can be seen in the visualization of figure 3, we can analyze research of computational sociology in which it possesses several connected clusters or groups. From mapping carried out in this

6 Official website of Social Science Computer Review: http://journals.sagepub.com/home/ssc/ impact factor 3.253 
research, there are at least four main clusters mapped from diverse fundamental concepts and keywords generally utilized by researchers in computational sociology literature such as computational method, computational ethnography, computational linguistics, and social theory. In addition, there are several important concepts excluding four clusters in which these clusters are connected with others such as computational complexity, big data, and agent-based modeling. Each of the clusters and concepts will be highlighted in the description and subsequent review of collected literature.

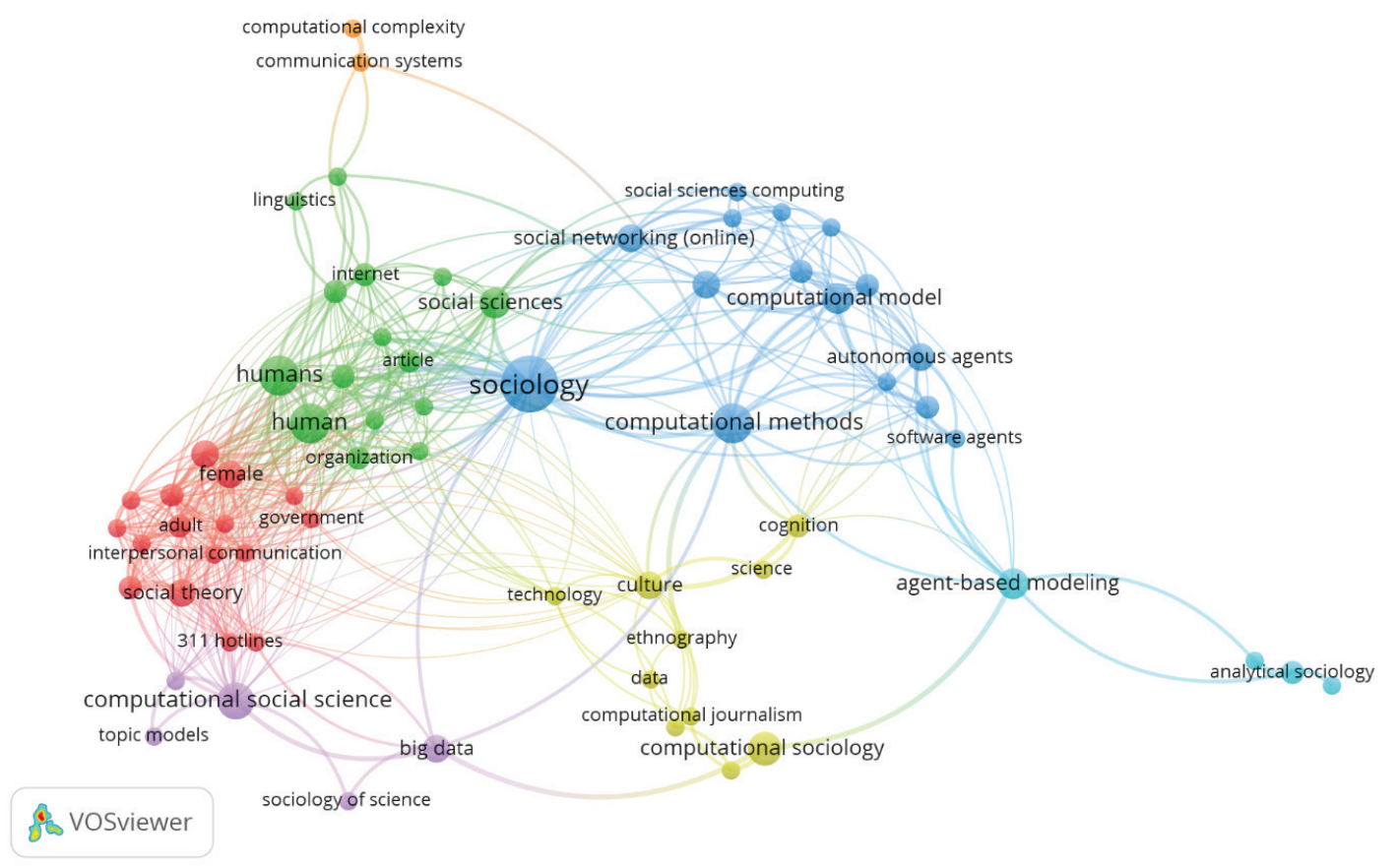

Figure 3. Visualization of fundamental keywords used by researchers in the database including seventy articles, all keywords co-occurrence depicts the connectivity among concepts in the study of contemporary computational sociology. It was created by the Vosviewer program, an open sources application developed by Nees Jan Van Eck and Ludo Waltman from Leiden University, Netherland ${ }^{7}$. Color similarity reveals the similarity of clusters. Moreover, the distance among concepts shows closeness use by researchers.

Computational Methods for Social to measure the level of the free will of victims

\section{Research}

The novelty method for creating simulations or computational models possesses diverse approaches as well as sociological objectives. The results of a study from Khan et al (2018), for instance, attempt of domestic sexual violence ${ }^{8}$ and children sexual exploitation ${ }^{9}$. They attempt to amplify what are challenges faced by victims if they want to escape from violence situation and exploitation particularly between female and male victims. Quantitatively, modeling free will

7 The application can be downloaded for free here: http://www.vosviewer.com/download

8 or referred to by the term of victims of domestic minor sex trafficking (VDMST)

9 referred to by the term of commercially sexually exploited children (CSEC)). 
and opportunity to truly be free is apparently uneasy. In addition, there are several variables they find, for instance, whether they are linked to street work, homeless, consuming marijuana or cocaine, whether or not there is an alternative income and so on resulting in the probability of escaping from sexual violence and exploitation. Such an approach is certainly absorbing where it reinforces theories highlighting why sex workers often escape from the situation that ensnares them.

The popular method in computational sociology is the Agent-Based Model (ABM). It is a computational method allowing researchers to create, analyze, and attempt various models containing interactions among "agent" and "environment" (Gilbert, 2008). Although it has long been applied to the science field, it can be conveyed to be a relatively new method in social science studies, particularly in Indonesia. The basic idea derives from the desire of social scientists to create a model that is able to represent current social phenomena. Creating models of artificial societies is the aim of ABM simulation (Epstein \& Axtell, 1996). If pilots recognize flight simulator to practice various possibilities of flying an airplane, then ABM is a tool for social scientists in observing various possibilities of the agent or individual behavior in certain social phenomena.

Moreover, several literature reviews in this article found several ABM-based studies. One of them was written by Zea et al (2018) modeling "population desegregation" based on the influence of group leader. It was inspired by the biological evolution of an ant queen in organizing her colonies which are commonly called as The Foundress Dilemma. We can observe the extent to which the role of group leader in creating segregation and desegregation of members in their community. Ahrweiler (2017) utilized ABM to make a simulation on the process of drafting Science, Technology, and Innovation (STI) policy. He attempts to combine empirical data by placing "what-if questions" in each scenario of his computerizes model. Furthermore, ABM is considered capable enough to predict the result of various policy scenario where if scenario and experiment are conducted in the real world. It will require a lot of time and budget. A critical review of Zhang \& Vorobeychik (2017) on the use of $\mathrm{ABM}$ in empirical research on diffusion and innovation is likely to assist us in grasping the advantage and disadvantage of the ABM approach.

\section{Computational Ethnography}

Fascinating development related to the influence of computing in several methods of social research was also appeared in discussion developing among ethnographers. Ethnography is one of five approaches in social inquiry (Craswell, 2008). Other approaches are narratives, phenomenology, case study, and grounded theory. These approaches certainly possess own ontological and 
epistemological differences. In ethnography, one of the main concerns is to provide a deep explanation of the culture of the community. An in-depth description of the culture resulted in many research reports that were valuable in field data. An ethnographic approach is often considered by the critics as insufficiently transparent in managing, collecting, analyzing, and presenting valuable field data. In today's computing era, there are emerging new approaches to strengthen transparency and to visualize ethnographic records. It is referred to as the "ethnorcracy analysis" (Abramson \& Dohan, 2015). It attempts to create visual interactive to analyse very rich ethnographic data with computer programming techniques such as CAQDAS (Computer-Assisted Qualitative Data Analysis Software) combining with several technical approaches such as PCA (Principle Component Analysis), SA (Sequence Analysis), MCA (Multiple Correspondence Analysis), QCA (Qualitative Comparative Analysis) and various linguistic algorithms.

The development is manifestly fascinating even though it will not be separated from the pros and cons of complicated debate among researchers and social scientists. The computational power in collecting, analyzing, and displaying social research data attractively is a center among social and non-social scientists in attempting to apply and develop this approach. Thomas HomerDixon et al (2013) offer a unique approach in dismantling ideology or political belief system with a method called CAM (CognitiveAffective Mapping). It was developed from techniques in cognitive science and social networking as well as from across disciplines such as psychology, sociology, and political science particularly exploring ideology. The mapping results with the CAM approach can be utilized to analyze text, survey result, and other data. In addition, the approach is valuable due to combining cognition in which it is the result of individual processes of molecular, neural, and psychological. In addition, collective mentality is the results of group social processes of communication and interaction. By reading the results of the analysis of the complexity of these individual and group, we will be able to grasp the political and ideological identity of a person and group according to the relevant core values in the group. The model of social cognition was also reviewed by Tibbets (20150 in his article on sociology and neuroscience where he observed "distance" as well as "closeness" between two disciplines possessing the potential to be connected through a computational sociology approach.

\section{Computational Linguistics}

Bohr and Dunlap (2017) conducted absorbing research by discussing computational text analysis to observe key topics in the field of environmental sociology studies from 1990 to 2014. As the field of science developed rapidly and widely, they considered examining how the branch 
of science developed. Using information sources, they managed to find twentyfive topic groups in the mainstream of Environmental sociology in which the top six topics are environmental, climate and society, environment and society, political economy and agriculture, and environmental inequality. The mapping is manifestly beneficial enough to analyze the interest of researchers in environmental sociology research based on writing and research they have conducted for more than the last twenty years.

In line with Bohr and Dunlap, Rose et al (2018), utilizes computational modeling to systematically dig topics discussed in the critics of contemporary art. They processed and analyzed 6,965 articles published between 1991 and 2015 at Frieze, a leading art magazine. As a result, they were able to determine the number of topics characterizing professional discourse about contemporary art, i.e. those related to media or genre of film, cinema, photography, sculpture, installation, and so on. In fact, by discovering the large images from the analysis of thousands of articles, they pinpointed extra-artistic topic characterizing contemporary art criticism. In addition to the computational method, they can draft the evolution of discourse in the field of contemporary art over the past twenty-five years.

Table 2. Comparison of Methods in Text Analysis

\begin{tabular}{llll}
\hline \multicolumn{1}{c}{ Approach } & \multicolumn{1}{c}{ Technique } & \multicolumn{1}{c}{ Strength } & \multicolumn{1}{c}{ Weakness } \\
\hline $\begin{array}{l}\text { Socio- } \\
\text { Historical } \\
\text { Interpretive) }\end{array}$ & $\begin{array}{l}\text { Thick description, } \\
\text { semiotic, interpretive } \\
\text { and so on }\end{array}$ & $\begin{array}{l}\text { Deep, focus on process, } \\
\text { narrative }\end{array}$ & $\begin{array}{l}\text { Broad, difficult } \\
\text { to determine the } \\
\text { starting point, large } \\
\text { resources and so } \\
\text { on. }\end{array}$ \\
\hline $\begin{array}{l}\text { Content } \\
\text { Analysis }\end{array}$ & $\begin{array}{l}\text { Reading and } \\
\text { Observing Text }\end{array}$ & $\begin{array}{l}\text { Systematic, able to utilize a } \\
\text { statistical model, reliable }\end{array}$ & $\begin{array}{l}\text { Limited resources, } \\
\text { less profound }\end{array}$ \\
\hline Narrative & $\begin{array}{l}\text { Grammar-Based, } \\
\text { Event-Based } \\
\text { Modeling }\end{array}$ & $\begin{array}{l}\text { Time and process, able to } \\
\text { process hundreds of texts }\end{array}$ & $\begin{array}{l}\text { Limited resources, } \\
\text { difficult to replicate }\end{array}$ \\
\hline $\begin{array}{l}\text { Word-Based } \\
\text { Networks }\end{array}$ & $\begin{array}{l}\text { Inter-word } \\
\text { networking, text } \\
\text { analysis, thematic } \\
\text { model }\end{array}$ & $\begin{array}{l}\text { Cheap, fast, intuitive, } \\
\text { process thousands of texts }\end{array}$ & $\begin{array}{l}\text { Less depth, multi- } \\
\text { interpretation } \\
\text { (polysemy) }\end{array}$ \\
\hline
\end{tabular}

The abundance of digital data has revolutionized how sociologists consume and produce data and information. The development of social media such as Twitter, for instance, has encouraged the invention of a myriad of tools for analysis of social networking, sentiment and social fragmentation analysis throughout the world. In computational linguistics and social science, the development is grasped with the popularity of the word-based network approach to responding to research problems. Analysis of social networking is not only popular for visualizing the latest 
issues on social media but can also be utilized in mapping organizations (Prasetyo, 2018) to social movements. As shown in table 2 above, the word-based networking approach possesses the strength of speed in the process and able to process a huge number of texts. In the digital age, speed is a difficult part to deny in which an issue will pass instantly and be replaced by a new issue and discourse. Therefore, it is absolutely necessary for a computational approach in order to respond to an issue as quickly and accurately as possible by researchers and policymakers.

\section{Social Theory and Computational}

Form the analysis of systematic review above, we discover symptoms that development of Big Data and digitalization of information not only results in a transformation in methods and techniques of collecting data but also alters our perspective on the data itself. Digital data is not only "big" and "infinite" but also diverse with variants. In addition, it appears a new terminology and approach called "forensic social science" possessing the potential to shift the direction of social science studies from structural-positivistic to more constructive-scientific (McFarland et al, 2015). Forensic social science not only offers a purely deductive approach as quantitative studies but also not purely inductive as a qualitative study. Furthermore, it combines two into a more generative approach and can increase the degree of application of social theory in the future (Brent et al., 2000). New research techniques attempting to uncover patterns and social relations among humans. Computational ethnography, computational linguistics, network science are only the initial markers of development of integrative forensic social science or computational sociology. In fact, experimental research has advanced in attempting to predict the results of interaction with machine learning.

\section{Conclusion}

A systematic review of scientific publication articles related to application and development of computational sociology at Scopus has split several study clusters such as studies of computational research methodology, computational linguistics, computational ethnography and development of social theories through computational approaches. In addition, a bibliometric analysis of scientific publication data has been able to categorize fundamental concepts. As a relatively new approach, computational sociology is still developing and will increasingly discover its relevance in the future. The application of a computational sociology approach is highly open particularly for those interested in Indonesia studies. The lack of international literature from homeland adopting the approach is expected to encourage enthusiasts of computational sociology for enduring development discourse on the complexity of social sciences and the need for integrating variously disciplined 
to respond these challenges. The review manifestly possesses limitations where publication data is taken only from Scopus data center, and only English-language articles are analyzed. In the next research, article publication data from other data centers are needed such as a web of science, science direct, Google scholar and so on. Analysis of similar articles utilizing Indonesian can be a valuable opportunity to examine the development of computational sociology in Indonesia.

\section{BIBLIOGRAPHY}

Abramson C.M., Dohan D. (2015), Beyond Text: Using Arrays to Represent and Analyze Ethnographic Data. Sociological Methodology, August 1; 45(1): $272-319$

Ahrweiler P. (2017), Agent-based simulation for science, technology, and innovation policy. Scientometrics, 110:391-415

Alvarez, Michael R (editor), (2016), Computational Social Sciences: Discovery and Prediction. Cambridge University Press

Bohr J., Dunlap R.E., (2018), Key Topics in environmental sociology, 19902014: results from computational text analysis. Environmental Sociology

Brent, Edward et al. (2000), Sociology: A Computational Approach to Sociological Explanations. Social Science Computer Review, Vol. 18 No. 2, Summer 2000 223-235

Epstein, Joshua M \& Ribert Axtell. (1996), Growing Artificial Societies: Social Science from the Bottom Up. The MIT Press

Gilbert, Nigel. (2008), Agent-Based Models. Sage Publications
Halford S., Savage M. (2017), Speaking Sociologically with Big Data: Symphonic Social Science and the Future for Big Data Research. Sociology, Vol. 51(6) $1132-1148$

Hummon N.P., Fararo T.J. (1995), The emergence of computational sociology. The Journal of Mathematical Sociology vol 20(2-3), pp 79-87

Homer-Dixon T., et al. (2013), A complex systems approach to the study of ideology: Cognitive-affective structures and the dynamics of belief systems, Journal of Social and Political Psychology, Vol. 1(1), 337-363

Light, R. (2014), From words to networks and back: Digital text, computational social science, and the case of presidential inaugural addresses. Social Currents 2014, Vol. 1(2) 111-129

McFarland D.A., Lewis K., Goldberg A. (2016), Sociology in the Era of Big Data: The Ascent of Forensic Social Science. American Sociologist, DOI 10.1007/ s12108-015-9291-8

Miller, John H \& ScottE. Page. (2007), Complex Adaptive Systems: An Introduction to 
Computational Models of Social Life. Zia K., et al. (2018), Nature-Inspired

Princeton University Press

Zhang H., Vorobeychik Y. (2017), Empirically grounded agent-based models of innovation diffusion: a critical review.

Artificial Intelligence Review
Computational Model of Population Desegregation under Group Leaders Influence. IEEE Transactions on Computational Social Systems.

Attachment 1. List of Publications for a Systematic review of the Topics of Computational Sociology at Scopus

\begin{tabular}{|c|c|c|c|c|}
\hline No & Authors & Title & Year & Source title \\
\hline 1 & $\begin{array}{l}\text { Khan B., Lee H.-W., } \\
\text { Thrash C.R., Dombrowski } \\
\text { K. }\end{array}$ & $\begin{array}{l}\text { Agency and social constraint } \\
\text { among victims of domestic } \\
\text { minor sex trafficking: A method } \\
\text { for measuring free will }\end{array}$ & 2018 & $\begin{array}{l}\text { Social Science } \\
\text { Research }\end{array}$ \\
\hline 2 & $\begin{array}{l}\text { Roose H., Roose W., } \\
\text { Daenekindt S. }\end{array}$ & $\begin{array}{l}\text { Trends in Contemporary } \\
\text { Art Discourse: Using Topic } \\
\text { Models to Analyze } 25 \text { years of } \\
\text { Professional Art Criticism }\end{array}$ & 2018 & $\begin{array}{l}\text { Cultural } \\
\text { Sociology }\end{array}$ \\
\hline 3 & $\begin{array}{l}\text { Zia K., Saini D.K., } \\
\text { Muhammad A., Ferscha } \\
\text { A. }\end{array}$ & $\begin{array}{l}\text { Nature-Inspired Computational } \\
\text { Model of Population } \\
\text { Desegregation under Group } \\
\text { Leaders Influence }\end{array}$ & 2018 & $\begin{array}{l}\text { IEEE } \\
\text { Transactions } \\
\text { on } \\
\text { Computational } \\
\text { Social Systems }\end{array}$ \\
\hline 4 & $\begin{array}{l}\text { Breiger R.L., Wagner- } \\
\text { Pacifici R., Mohr J.W. }\end{array}$ & $\begin{array}{l}\text { Capturing distinctions while } \\
\text { mining text data: Toward } \\
\text { low-tech formalization for text } \\
\text { analysis }\end{array}$ & 2018 & Poetics \\
\hline 5 & Edelmann A., Mohr J.W. & $\begin{array}{l}\text { Formal studies of culture: } \\
\text { Issues, challenges, and current } \\
\text { trends }\end{array}$ & 2018 & Poetics \\
\hline 6 & Foster J.G. & $\begin{array}{l}\text { Culture and computation: } \\
\text { Steps to a Probably } \\
\text { Approximately Correct theory of } \\
\text { culture }\end{array}$ & 2018 & Poetics \\
\hline 7 & Bohr J., Dunlap R.E. & $\begin{array}{l}\text { Key Topics in environmental } \\
\text { sociology, 1990-2014: results } \\
\text { from a computational text } \\
\text { analysis }\end{array}$ & 2018 & $\begin{array}{l}\text { Environmental } \\
\text { Sociology }\end{array}$ \\
\hline 8 & $\begin{array}{l}\text { Mogles N., Padget J., } \\
\text { Gabe-Thomas E., Walker } \\
\text { I., Lee J.H. }\end{array}$ & $\begin{array}{l}\text { A computational model for } \\
\text { designing energy behavior } \\
\text { change interventions }\end{array}$ & 2018 & $\begin{array}{l}\text { User Modeling } \\
\text { and User- } \\
\text { Adapted } \\
\text { Interaction }\end{array}$ \\
\hline 9 & $\begin{array}{l}\text { Ye P., Wang S., Wang } \\
\text { F.-Y. }\end{array}$ & $\begin{array}{l}\text { A General Cognitive } \\
\text { Architecture for Agent-Based } \\
\text { Modeling in Artificial Societies }\end{array}$ & 2018 & $\begin{array}{l}\text { IEEE } \\
\text { Transactions } \\
\text { on } \\
\text { Computational } \\
\text { Social Systems }\end{array}$ \\
\hline
\end{tabular}




\begin{tabular}{|c|c|c|c|c|}
\hline No & Authors & Title & Year & Source title \\
\hline 10 & Halford S., Savage M. & $\begin{array}{l}\text { Speaking Sociologically with } \\
\text { Big Data: Symphonic Social } \\
\text { Science and the Future for Big } \\
\text { Data Research }\end{array}$ & 2017 & Sociology \\
\hline 11 & Zhang H., Vorobeychik Y. & $\begin{array}{l}\text { Empirically grounded agent- } \\
\text { based models of innovation } \\
\text { diffusion: a critical review }\end{array}$ & 2017 & $\begin{array}{l}\text { Artificial } \\
\text { Intelligence } \\
\text { Review }\end{array}$ \\
\hline 12 & Hegselmann R. & $\begin{array}{l}\text { Thomas C. Schelling and } \\
\text { James M. Sakoda: The } \\
\text { intellectual, technical, and } \\
\text { social history of a model }\end{array}$ & 2017 & JASSS \\
\hline 13 & Ahrweiler P. & $\begin{array}{l}\text { Agent-based simulation for } \\
\text { science, technology, and } \\
\text { innovation policy }\end{array}$ & 2017 & Scientometrics \\
\hline 14 & $\begin{array}{l}\text { Shaw H., Ellis D.A., } \\
\text { Kendrick L.-R., Ziegler F., } \\
\text { Wiseman R. }\end{array}$ & $\begin{array}{l}\text { Predicting Smartphone } \\
\text { Operating System from } \\
\text { Personality and Individual } \\
\text { Differences }\end{array}$ & 2016 & $\begin{array}{l}\text { Cyberpsy- } \\
\text { chology, } \\
\text { Behavior, } \\
\text { and Social } \\
\text { Networking }\end{array}$ \\
\hline 15 & Alvarez-Galvez J. & $\begin{array}{l}\text { Network Models of Minority } \\
\text { Opinion Spreading: Using } \\
\text { Agent-Based Modeling to Study } \\
\text { Possible Scenarios of Social } \\
\text { Contagion }\end{array}$ & 2016 & $\begin{array}{l}\text { Social Science } \\
\text { Computer } \\
\text { Review }\end{array}$ \\
\hline 16 & Bail C.A. & $\begin{array}{l}\text { Cultural carrying capacity: } \\
\text { Organ donation advocacy, } \\
\text { discursive framing, and social } \\
\text { media engagement }\end{array}$ & 2016 & $\begin{array}{l}\text { Social Science } \\
\text { and Medicine }\end{array}$ \\
\hline 17 & Liu H., Guo G. & $\begin{array}{l}\text { Opportunities and challenges of } \\
\text { big data for the social sciences: } \\
\text { The case of genomic data }\end{array}$ & 2016 & $\begin{array}{l}\text { Social Science } \\
\text { Research }\end{array}$ \\
\hline 18 & $\begin{array}{l}\text { Evans E.D., Gomez C.J., } \\
\text { McFarland D.A. }\end{array}$ & $\begin{array}{l}\text { Measuring paradigmatic ness } \\
\text { of disciplines using text }\end{array}$ & 2016 & $\begin{array}{l}\text { Sociological } \\
\text { Science }\end{array}$ \\
\hline 19 & $\begin{array}{l}\text { Elsenbroich C., Verhagen } \\
\text { H. }\end{array}$ & $\begin{array}{l}\text { The simplicity of complex } \\
\text { agents: a Contextual Action } \\
\text { Framework for Computational } \\
\text { Agents }\end{array}$ & 2016 & $\begin{array}{l}\text { Mind and } \\
\text { Society }\end{array}$ \\
\hline 20 & $\begin{array}{l}\text { McFarland D.A., Lewis K., } \\
\text { Goldberg A. }\end{array}$ & $\begin{array}{l}\text { Sociology in the Era of Big } \\
\text { Data: The Ascent of Forensic } \\
\text { Social Science }\end{array}$ & 2016 & $\begin{array}{l}\text { American } \\
\text { Sociologist }\end{array}$ \\
\hline 21 & Tibbetts P. & $\begin{array}{l}\text { Sociology and Neuroscience: An } \\
\text { Emerging Dialogue }\end{array}$ & 2016 & $\begin{array}{l}\text { American } \\
\text { Sociologist }\end{array}$ \\
\hline 22 & $\begin{array}{l}\text { O’Brien D.T., Sampson } \\
\text { R.J., Winship C. }\end{array}$ & $\begin{array}{l}\text { Ecometrics in the Age of Big } \\
\text { Data: Measuring and Assessing } \\
\text { "Broken Windows" Using Large- } \\
\text { scale Administrative Records }\end{array}$ & 2015 & $\begin{array}{l}\text { Sociological } \\
\text { Methodology }\end{array}$ \\
\hline 23 & Abramson C.M., Dohan D. & $\begin{array}{l}\text { Beyond Text: Using Arrays } \\
\text { to Represent and Analyze } \\
\text { Ethnographic Data }\end{array}$ & 2015 & $\begin{array}{l}\text { Sociological } \\
\text { Methodology }\end{array}$ \\
\hline
\end{tabular}




\begin{tabular}{|c|c|c|c|c|}
\hline No & Authors & Title & Year & Source title \\
\hline 24 & $\begin{array}{l}\text { Shor E., van de Rijt A., } \\
\text { Miltsov A., Kulkarni V., } \\
\text { Skiena S. }\end{array}$ & $\begin{array}{l}\text { A Paper Ceiling: Explaining the } \\
\text { Persistent Underrepresentation } \\
\text { of Women in Printed News }\end{array}$ & 2015 & $\begin{array}{l}\text { American } \\
\text { Sociological } \\
\text { Review }\end{array}$ \\
\hline 25 & Light R. & $\begin{array}{l}\text { From words to networks } \\
\text { and back: Digital text, } \\
\text { computational social science, } \\
\text { and the case of presidential } \\
\text { inaugural addresses }\end{array}$ & 2014 & $\begin{array}{l}\text { Social } \\
\text { Currents }\end{array}$ \\
\hline 26 & Manzo G. & $\begin{array}{l}\text { Reason-based explanations and } \\
\text { analytical sociology. A rejoinder } \\
\text { to boudon [Explicaciones } \\
\text { basadas en razones y sociología } \\
\text { analítica. Una réplica a } \\
\text { Boudon] }\end{array}$ & 2014 & Papers \\
\hline 27 & McClelland K. & $\begin{array}{l}\text { Cycles of conflict: A } \\
\text { computational modeling } \\
\text { alternative to Collins's theory of } \\
\text { conflict escalation }\end{array}$ & 2014 & $\begin{array}{l}\text { Sociological } \\
\text { Theory }\end{array}$ \\
\hline 28 & Anderson C.W. & $\begin{array}{l}\text { Towards a sociology of } \\
\text { computational and algorithmic } \\
\text { journalism }\end{array}$ & 2013 & $\begin{array}{l}\text { New Media } \\
\text { and Society }\end{array}$ \\
\hline 29 & Manzo G. & $\begin{array}{l}\text { Is rational choice theory still } \\
\text { a rational choice of theory? A } \\
\text { response to Opp }\end{array}$ & 2013 & $\begin{array}{l}\text { Social Science } \\
\text { Information }\end{array}$ \\
\hline 30 & $\begin{array}{l}\text { Homer-Dixon T., Maynard } \\
\text { J.L., Mildenberger M., } \\
\text { Milkoreit M., Mock S.J., } \\
\text { Quilley S., Schröder T., } \\
\text { Thagard P. }\end{array}$ & $\begin{array}{l}\text { A complex systems approach } \\
\text { to the study of ideology: } \\
\text { Cognitive-affective structures } \\
\text { and the dynamics of belief } \\
\text { systems }\end{array}$ & 2013 & $\begin{array}{l}\text { Journal of } \\
\text { Social and } \\
\text { Political } \\
\text { Psychology }\end{array}$ \\
\hline 31 & $\begin{array}{l}\text { Cederman L.-E., Girardin } \\
\text { L. }\end{array}$ & $\begin{array}{l}\text { Growing sovereignty: Modeling } \\
\text { the shift from indirect to direct } \\
\text { rule }\end{array}$ & 2010 & $\begin{array}{l}\text { International } \\
\text { Studies } \\
\text { Quarterly }\end{array}$ \\
\hline 32 & $\begin{array}{l}\text { Bankes S., Lempert R., } \\
\text { Popper S. }\end{array}$ & $\begin{array}{l}\text { Making computational social } \\
\text { science effective: Epistemology, } \\
\text { methodology, and technology }\end{array}$ & 2002 & $\begin{array}{l}\text { Social Science } \\
\text { Computer } \\
\text { Review }\end{array}$ \\
\hline 33 & $\begin{array}{l}\text { Brent E., Thompson A., } \\
\text { Vale W. }\end{array}$ & $\begin{array}{l}\text { A computational approach to } \\
\text { sociological explanations }\end{array}$ & 2000 & $\begin{array}{l}\text { Social Science } \\
\text { Computer } \\
\text { Review }\end{array}$ \\
\hline 34 & Brent Jr. E.E. & $\begin{array}{l}\text { Expert systems and their role } \\
\text { in computational sociology }\end{array}$ & 1996 & $\begin{array}{l}\text { Sociological } \\
\text { Methods and } \\
\text { Research }\end{array}$ \\
\hline 35 & Carley K.M. & $\begin{array}{l}\text { Artificial intelligence within } \\
\text { sociology }\end{array}$ & 1996 & $\begin{array}{l}\text { Sociological } \\
\text { Methods and } \\
\text { Research }\end{array}$ \\
\hline 36 & Hummon N.P., Fararo T.J. & $\begin{array}{l}\text { The emergence of } \\
\text { computational sociology }\end{array}$ & 1995 & $\begin{array}{l}\text { The Journal of } \\
\text { Mathematical } \\
\text { Sociology }\end{array}$ \\
\hline
\end{tabular}

